\title{
Plant Spacing: A Key Husbandry Practice for Rainy Season Cabbage Production
}

\author{
Purushottam P Khatiwada \\ Agriculture Research Station, Pakhribas, Nepal
}

\begin{abstract}
A field experiment was accomplished to establish appropriate plant spacing for summer season cabbage production in the rain fed condition of the high hills of eastern Nepal. The experiment was conducted during the summer of 1997, 1998 and 1999. Five different plant spacings (45- $\times$ $60-\mathrm{cm}, 45-\times 50-\mathrm{cm}, 45-\times 40-\mathrm{cm}, 45-\times 30-\mathrm{cm}$ and $45-\times 20-\mathrm{cm})$ and two varieties, Green Stone and Green Coronet were tested. The interactive effect between variety and spacing was nonsignificant. However, among the tested spacings, head yields were statistically higher at $45-\times 30$ $\mathrm{cm}$ and $45-\times 20-\mathrm{cm}$ plant spacings. There was a positive linear correlation between closer plant spacing and cabbage head yield. The number of unmarketable heads and the lowest head compactness was recorded in $45-\times 20-\mathrm{cm}$ spacing. Spacing of $45-\times 30-\mathrm{cm}$ was found more economical. Plant population can be maintained as high as 74,074 number ha $^{-1}$ by decreasing the spacing from $75-\times 60-\mathrm{cm}$ to $45-\times 30-\mathrm{cm}$ for the rainy season cabbage cultivation in high hills. By using this spacing, as high as $35 \mathrm{t} \mathrm{ha}^{-1}$ cabbage head can be produced in the rainfed condition of the high hills.
\end{abstract}

Key words: Cabbage, hybrid, plant spacing, rainy season

\section{Introduction}

The potential yield of cabbage (Brassica oleraceae var. capitata) is determined by appropriate husbandry practices and the surrounding environment provided to the crop. Among the husbandry practices, a direct effect can be observed due to an increase or a decrease in plant population because a cabbage plant bears a single head. However, serious thoughts have not been given in this aspect in Nepal (VDD, 1987; Rai and Gauchan, 1987). Vegetable Development Division (VDD) of Department of Agriculture has recommended $45-\times 45-\mathrm{cm}$ and $75-\times 60-\mathrm{cm}$ between and within row plant spacings respectively for early and late season cabbage production (VDD, 1987). In a cultivar evaluation trial in May sowing under Marpha condition, Rai and Gauchan (1987) used a spacing of $45-\times 30-\mathrm{cm}$ for a variety Pride of India. However, they used $60-\times 30-\mathrm{cm}$ for Late Large Drum Head, September and Danish Ball without giving the basis of selecting different spacings for different tested varieties. A spacing trial on cabbage indicated the highest head yield of cultivar Pride of India at $40-\times 30-\mathrm{cm}$ plant spacing (Gurung, 1985). However, Agriculture Research Station, Pakhribas (then PAC) recommended $60-\times 45-\mathrm{cm}$ plant spacing for cabbage cultivation for winter as well as rainy season (PAC, 1990).

As in Nepal, different plant spacings have been tried in other countries (Berard, 1990; Subba, 1991). In the Sikkim hills, which has similar climatic conditions to that of the eastern hills of Nepal, spacings, $45-\times 45-\mathrm{cm}$ and $60-\times 45-\mathrm{cm}$ have been recommended for early as well as mid and late season, respectively (Subba, 1991). In a comparison between $60-\times 60-\mathrm{cm}$ and $60-\times 45-$ $\mathrm{cm}$ spacings, the higher cabbage head yield (22.9 $\mathrm{t} \mathrm{ha}^{-1}$ ) was obtained from the closer spacing than that from the wider one $\left(20.7 \mathrm{t} \mathrm{ha}^{-1}\right)$ with the cultivar Pusa Drum Head (Mallik and Bhattacharya, 1996). Another study conducted by Lal (1996) showed that cabbage variety Golden Acre yielded $24.5 \mathrm{tha}^{-1}$ at a spacing of $30-\times 60$ $\mathrm{cm}$ and $18.47 \mathrm{tha}^{-1}$ at a spacing of $60-\times 60-\mathrm{cm}$. In contrast, Berard (1990) used 90- $\times 45-\mathrm{cm}$ plant 
spacing in Canada, but the Canadian situation does not resemble ours.

Under farmers' field condition, even the plant spacing $(60-\times 45-\mathrm{cm})$ recommended by PAC was found inappropriate, especially with the hybrids leading to an improper utilization of available land, light and nutrition. Farmers have been maintaining a wide range of plant population ranging between 50,000 and 100,000 plants ha $^{-1}$ (Khatiwada and Gupta, 1997). The above mentioned plant population is far higher than the recommended plant population $(37,037$ plants $\mathrm{ha}^{-1}$ ) for normal and late season planting (VDD, 1987).

As cabbage is an important commercial vegetable in Nepal (APROSC and JMA, 1995), an extensive research has been carried out at Pakhribas for all year-round production. Hybrid varieties have been found suitable for rainy season production (PAC, 1990). As a result, a large number of hybrids is extensively cultivated, particularly during the seasons other than that of winter in the eastern hills. The previously recommended hybrid, KK Cross (Thapa et al., 1997) has been replaced by new hybrids, Green Stone and Green Coronet due to their small and tight heads and they have relatively better storability and easy to market (Tiwari et al., 1996). Informal discussion with semi-commercial cabbage growers revealed that closer plant spacing leads to produce relatively smaller heads, despite having genetic potential for large head size. Owing these considerations, this experiment was conducted to determine the effect of plant spacings on the head yield of cabbage hybrids.

\section{Materials and Methods}

Two popular hybrid varieties, Green Coronet and Green Stone were selected for this experiment. The experiment was conducted at Sindhuwa (2200 masl) of Dhankuta district during the summer in 1997, 1998 and 1999. After analyzing the first year's research results five different plant spacings $(45-\times 60-\mathrm{cm}, 45-\times 50-\mathrm{cm}, 45-\times 40-$ $\mathrm{cm}, 45-\times 30-\mathrm{cm}$ and $45-\times 20-\mathrm{cm})$ and two varieties (Green Stone and Green Coronet) were tested using two factors factorial randomized complete block design with three replications during the spell later two consecutive years. The experimental area was east facing with sandy loam soil.

Six metres long and 1 metre wide individual nursery was made for each variety. Compost at the rate of $5 \mathrm{~kg} \mathrm{~m}^{-2}$ and Malathion dust at the rate of $1 \mathrm{~g} \mathrm{~m}^{-2}$ were applied in the nursery. Seeds were sown in the second week of May under shade. In the first year, seed was sown in the third week of May. Mulching was done immediately after sowing followed by watering. One weeding and one spraying of Indofil M-45 (Mancozeb) at the rate of $2 \mathrm{~g} \mathrm{l}^{-1}$ were performed in the nurseries.

Farm yard manure was applied at the rate of $33 \mathrm{t}$ $\mathrm{ha}^{-1}$ and it was incorporated into the soil during land preparation. At the final stage of land preparation, Malathion (5\% dust) @ $20 \mathrm{~kg} \mathrm{ha}^{-1}$ and chemical fertilizers at the rate of $60: 60: 30 \mathrm{~kg}$ $\mathrm{N} \mathrm{P}_{2} \mathrm{O}_{5} \mathrm{~K}_{2} \mathrm{O}$ ha $^{-1}$ were applied. Thirty to thirtyone day old seedlings were transplanted onto the experimental field in the second week of June (in the first year, where 34-day old seedlings were transplanted in the last week of June). The moisture level was sufficient in the field, hence, irrigation was not applied. To maintain the required plant population, gaps (plants killed by cutworms and red ants) were filled. To minimize the damage, Cyperin-10 (cypermethrine) at the rate of $1.5 \mathrm{ml} \mathrm{l}^{-1}$ of water was drenched 2-3 times in the experimental plots. Seedling mortality was compensated by gap filling even at the later stages in order to provide adequate competition using plants from the boarder rows. Plants transplanted at later stages (within 15 days after transplanting) were marked and excluded for the analysis.

Nitrogen was first top-dressed at the rate of $30 \mathrm{~kg}$ ha $^{-1}$ after 30 days of transplanting. Weeding was done prior to the second top-dressing. The second top-dressing was done 45 days after transplanting applying the same dose of nitrogen as in the first top-dressing. Weeding was further carried out at a month intervals. During the whole growing season, 1-2 sprayings of insecticides (metacid-a 
methyl parathion, at the rate of $2 \mathrm{ml} \mathrm{l}^{-1}$ ) and fungicide (Indofil M-45 at the rate of $2 \mathrm{~g} \mathrm{l}^{-1}$ ) were applied. Cabbage heads were harvested when they matured physiologically. Physiological maturity was assessed on the basis of head firmness. In addition to the marketable head weight, other parameters like unmarketable head weight, total upper ground biomass, outer leaf number, head polar as well as equatorial diameter, leaf length, leaf diameter and disease as well as insect incidences were recorded. Leaf length was measured by taking average of five leaves (outer, middle and inner leaves) of 10 plants. As in leaf length, leaf breadth was measured by taking average of five leaves (outer, middle and inner leaf) of 10 plants. After completion of the crop harvest, representative soil samples were collected from each plot. Soil samples were analyzed for nitrogen, phosphorus, potash and organic matter for the crop season, 1999. Calculation was done to know the gross income from cabbage cultivation in the rainy season in the high hills. Market price at the time of harvest was recorded based on Sindhuwa Cooperative. The data collected from the experiment were analyzed using GENSTAT 5 statistical package.

\section{Results and Discussion}

\section{Marketable head weight}

During the first year of the experiment, the effect of spacing was highly significant $(\mathrm{P}<0.001)$. At the spacing of $45-\times 30-\mathrm{cm}$, cabbage variety Green Coronet produced the highest yield $(61.2 \mathrm{t}$ $\mathrm{ha}^{-1}$ ), which was significantly higher than those obtained from rest of the spacings. The widest spacing $(60-\times 60-\mathrm{cm})$ produced the lowest yield $\left(30.2 \mathrm{t} \mathrm{ha}^{-1}\right)$, which was significantly lower than those of other tested spacings. The combined analysis of the second and the third year results revealed that the effect of spacing $(\mathrm{P}<0.01)$, varieties $(\mathrm{P}<0.05)$ and year $(\mathrm{P}<0.05)$ were significant (Table 1). However, their interaction was non-significant. Hence, only the mean values have been presented.

The results clearly demonstrated that the increased yield was obtained with the decreasing plant spacing. There was linear relationship between plant spacing and marketable head yield (Fig. 1).

Table 1. Mean marketable head yield of cabbage in association with plant spacing, variety and year

\begin{tabular}{|c|c|c|c|c|c|}
\hline Plant spacing, $\mathrm{cm}$ & Head yield, $\mathrm{t} \mathrm{ha}^{-1}$ & Variety & Head yield, $\mathrm{t} \mathrm{ha}^{-1}$ & Year & Head yield, $\mathrm{t} \mathrm{ha}^{-1}$ \\
\hline $45 \times 20$ & 39.90 & Green Coronet & 33.98 & $1997 / 98$ & 29.75 \\
\hline $45 \times 30$ & 35.89 & Green Stone & 29.76 & $1998 / 99$ & 33.99 \\
\hline $45 \times 40$ & 31.14 & & & & \\
\hline $45 \times 50$ & 29.15 & & & & \\
\hline $45 \times 60$ & 23.27 & & & & \\
\hline LSD & 5.43 & & & & \\
\hline $\mathrm{P}$ value & $<0.001$ & & 0.023 & & 0.014 \\
\hline
\end{tabular}




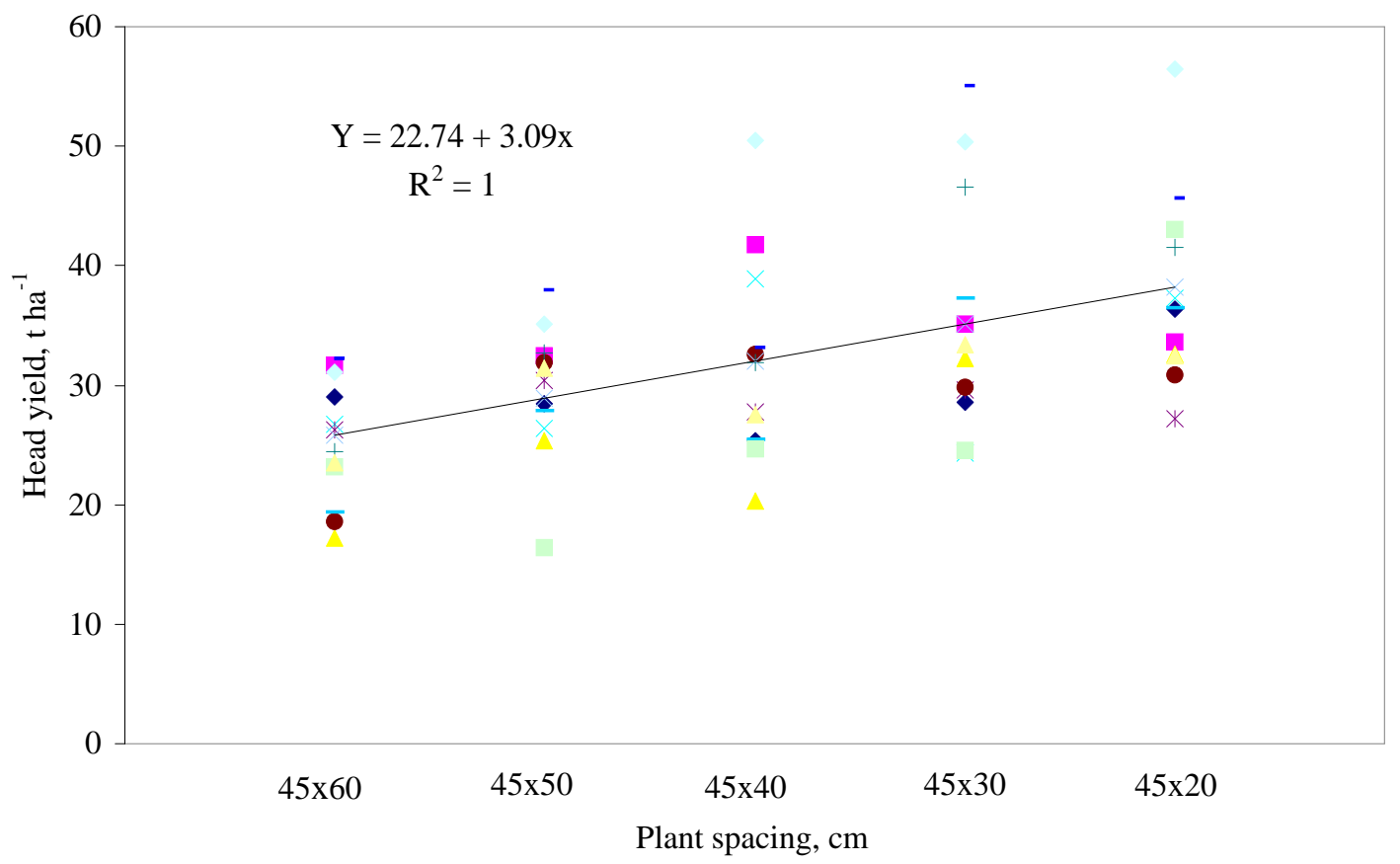

Fig 1. Relationship between cabbage head yield with the spatial plant spacing.

The linear regression analysis of head yield against plant spacing showed a very strong relationship (Fig. 1). Past results have shown that cabbage can be produced throughout the year in the upper mid-hills and high hills of the eastern Nepal (PAC, 1990). As a result the use of hybrids in the summer season has been increased dramatically in the road access areas of the eastern hills (Khatiwada, 1998). The higher yield from the closest spacing proved that the recommended spacing $(60-\times 45-\mathrm{cm})$ was too wide for summer season production. Marketable head yield was found higher than the national average $\left(9.7 \mathrm{t} \mathrm{ha}^{-1}\right)$ as reported by Shrestha and Ghimire (1996) even in summer season with recommended spacing. This could be due to cultivation of cabbage hybrids. More than $35 \mathrm{t}^{-}$ ${ }^{1}$ marketable head yields were recorded from 45 $\times 20-\mathrm{cm}$ and $45-\times 30-\mathrm{cm}$ spacings. A nonsignificant yield difference between $45-\times 20-\mathrm{cm}$ and $45-\times 30-\mathrm{cm}$, and significantly higher number of unmarketable head number (primarily due to loose heads) along with total upper ground biomass with rest of the spacings suggest that 45$\times 30-\mathrm{cm}$ spacing should be recommended to farmers. It also eases intercultural operations and needs lower amount of seed. Therefore, it can be recommended to double plant population $(74,074$ $\mathrm{ha}^{-1}$ ) as compared to that of previously recommended plant population $\left(37,037 \mathrm{ha}^{-1}\right)$. This result supports the findings made on cabbage spacing by other workers (Gurung, 1985; Rai and Gauchan, 1987).

\section{Head compactness}

Interaction effects of spacing, variety and year were not significantly different. Similarly, head compactness was not significant due to varieties. However, the effect of spacing was significant ( $\mathrm{P}$ $<0.01$ ) on head compactness (Table 2). Head compactness was the highest in $60-\times 45-\mathrm{cm}$ and the lowest in $45 \times 20-\mathrm{cm}$ spacings. The difference was not statistically detectable between $60-\times 45-\mathrm{cm}$ and $45-\times 40-\mathrm{cm}$ at the upper limit and $45-\times 30-\mathrm{cm}$ and $45-\times 20-\mathrm{cm}$ at the lower side. Results further showed that increasing the plant population also decreased the head compactness up to a certain level. The head compactness from the close spacing was, however, quite acceptable to the local market. 


\section{Head weight}

Effects of plant spacing and varieties on the individual head weight of cabbage as a single factor were found different $(\mathrm{P}<0.01)$. In contrast to that, the interaction effects of spacing and variety were not reckoned significantly different.

An average head weight of the variety Green Stone was lower than that of Green Coronet (Table 2). Similarly, it is apparent from the Table 1 that the head weight was different between 45 - $\times 20-\mathrm{cm}, 45-\times 30-\mathrm{cm}$ and $45-\times 40-\mathrm{cm}$ spacings but was not different in $45-\times 50-\mathrm{cm}$ and $45-\times$ 60 -cm spacings. Among these spacings, desirable head weight of $408 \mathrm{~g}$ in $45-\times 20-\mathrm{cm}$ and $566 \mathrm{~g}$ in $45-\times 30-\mathrm{cm}$ were obtained. Experience has shown that vegetable consumers like cabbage heads having an average weight of around $500 \mathrm{~g}$. The result also shows that increasing plant population per unit area decreases the head weight simultaneously.

Table 2. Individual cabbage head weight as affected by plant spacings and varieties

\begin{tabular}{|c|c|c|c|}
\hline Plant spacing, cm & Head weight, g & Variety & Head weight, g \\
\hline $45 \times 20$ & 408.0 & Green Stone & 611.0 \\
\hline $45 \times 30$ & 566.0 & Green Coronet & 713.0 \\
\hline $45 \times 40$ & 672.0 & & \\
\hline $45 \times 50$ & 824.0 & & \\
\hline \multirow[t]{3}{*}{$45 \times 60$} & 839.0 & & \\
\hline & 95.3 & & \\
\hline & $<0.001$ & $>0.05$ & $\leq 0.01$ \\
\hline
\end{tabular}

\section{Cropping duration}

Green Stone was ready for the first harvest after 67 days of transplanting and was harvested till 134 days after transplanting (DAT). However, Green Coronet took 92 days for the first harvest and lasted for 139 DAT. Effects of spacings were pronounced in Green Stone, in which harvesting could be done up to 83 DAT in the widest spacing and 134 DAT in the closest spacing. The effect was very little in Green Coronet, in which difference between close and wide spacing on DAT was only 9 days.

\section{Unproductive plant number}

Non-headed and stalk rot disease affected plants were regarded as the unproductive ones. There were very few stalk rot affected heads in the experimental plots. The analysis of variance showed significantly $(\mathrm{P}<0.001)$ higher number (7.25 in number from the area of $5.04 \mathrm{~m}^{2}$ ) of unproductive plants at $45-\times 20-\mathrm{cm}$ and this was followed by $45-\times 30-\mathrm{cm}$ (4.21 in number from $5.05 \mathrm{~m}^{2}$ ). The unproductive plants were not significantly different among the $45-\times 40-\mathrm{cm}$, $45-\times 50-\mathrm{cm}$ and $45-\times 60-\mathrm{cm}$ plant spacings.

\section{Plant height}

Plant height was not significantly different among different plant spacings, varieties and years. Similarly, the interaction effects on spacing and variety were not different. Furthermore, different plant spacings failed to show statistical differences in plant height. However, Green Coronet was found taller (27.52 $\mathrm{cm})$ than that of Green Stone $(23.44 \mathrm{~cm})$.

\section{Plant spreading}

Plant spreading was significantly $(\mathrm{P}<0.001)$ influenced by spacings and varieties. The result showed that closer spacing was not enough for the proper plant spreading (Table 3). However, the interaction effect between spacing and variety was not different. Similarly, the combined interaction effects among spacings, varieties and years were not significantly different. 
Table 3. Cabbage plant spreading as affected by plant spacings and varieties

\begin{tabular}{|c|c|c|c|}
\hline Plant spacing, $\mathrm{cm}$ & Spreading, $\mathrm{cm}$ & Variety & Spreading, $\mathrm{cm}$ \\
\hline $45 \times 20$ & 32.53 & Green Stone & 41.23 \\
\hline $45 \times 30$ & 36.06 & Green Coronet & 35.10 \\
\hline $45 \times 40$ & 37.90 & & \\
\hline $45 \times 50$ & 42.12 & & \\
\hline $45 \times 60$ & 42.20 & & \\
\hline LSD & 2.946 & & \\
\hline$P$ value & $<0.01$ & & $<0.001$ \\
\hline
\end{tabular}

\section{Leaf length}

Leaf length was not influenced significantly by plant spacing, varieties and their interactions. The mean leaf length irrespective of varieties and spacings was $22.8 \mathrm{~cm}$.

\section{Leaf breadth}

Statistical difference $(\mathrm{P}<0.001)$ was noted in the leaf breadth at different plant spacings. Furthermore, weaker evidence $(\mathrm{P}<0.05)$ was shown by varieties and interaction between varieties and spacings (Table 4). However, interaction effect of year, variety and spacing was not prominent.

\section{Outer leaf number}

Strong evidence was shown that the effect of spacing and variety was prominent on outer leaf number. The widest spacing $(60-\times 45-\mathrm{cm})$ produced the highest number (9.71) of outer leaves and was significantly different $(\mathrm{P}<0.01)$ from $45-\times 40-\mathrm{cm}, 45-\times 30-\mathrm{cm}$ and $45-\times 20-\mathrm{cm}$ but not from $45-\times 50-\mathrm{cm}$. The rest of the spacings were not different. Green Stone produced significantly higher number (9.43) of leaves than that of Green Coronet (8.79).

\section{Upper ground biomass}

The interaction effects between spacing and variety was not different on the total production of upper ground biomass. However, the effect of spacing was significant at $\mathrm{P}<0.01$ level. The total upper ground biomass production from 45 $\times 20-\mathrm{cm}, 45-\times 30-\mathrm{cm}, 45-\times 40-\mathrm{cm}, 45-\times 50-\mathrm{cm}$ and $45-\times 60-\mathrm{cm}$ were $53.9 \mathrm{t} \mathrm{ha}^{-1}, 48.1 \mathrm{t} \mathrm{ha}^{-1}, 44.2$ $\mathrm{t} \mathrm{ha}^{-1}, 42.2 \mathrm{t} \mathrm{ha}^{-1}$ and $34.1 \mathrm{t} \mathrm{ha}^{-1}$, respectively. Productions from all spacings except $45-\times 40-\mathrm{cm}$ and $45-\times 50-\mathrm{cm}$, were significantly different.

\section{Diseases and insects}

Alterneria leaf spot (Alternaria brassicae) and stalk rot (Screrotinia sclerotiorum) were two diseases recorded in the experimental plots. Alterneria leaf spot disease severity was scored $12-21 \%$ on lower leaves. The lower level of the disease was recorded in the wider spacing and higher level in the closer spacing. A maximum of $6 \%$ cabbage heads were found infected by stalk rot in the experimental plots but there was no relation between number of stalk rot affected plants and plant spacings. Cutworm (Agotis segatum) attack was found severe during the establishment phase of transplanted cabbage. Similarly, red ant (Dorylus orientalis) attack was also found severe in the experimental plots.

Table 4. Effects of spacings on leaf breadth of two cabbage varieties, Green Coronet and Green Stone

\begin{tabular}{|c|c|c|}
\hline \multirow[t]{2}{*}{ Plant spacing, $\mathrm{cm}$} & \multicolumn{2}{|c|}{ Leaf breath, $\mathrm{cm}$} \\
\hline & Green Coronet & Green Stone \\
\hline $45 \times 20$ & 15.60 & 16.94 \\
\hline $45 \times 30$ & 17.13 & 19.37 \\
\hline $45 \times 40$ & 18.93 & 18.62 \\
\hline $45 \times 50$ & 19.7 & 19.19 \\
\hline $45 \times 60$ & 18.78 & 19.83 \\
\hline LSD & & 1.42 \\
\hline$P$ value & $>0.05$ & $<0.05$ \\
\hline
\end{tabular}




\section{Major nutrients exhaustion}

Analysis of variance revealed that the nutrient depletion level was not significant due to plant spacings. Many positive attributes have been associated in the farming system due to close planting. Perusal of meteorological data recorded in the experimental site revealed that roughly one half of the annual rainfall was recorded between July and Sept. Besides, yield advantage, close planting reduced soil erosion and also suppressed weed infestation due to ground cover by cabbage plants during the period of high rainfall. The increase in $10 \mathrm{~cm}$ plant to plant distance without losing head yield meant, principally, there would be less nutrient mining. However, this notion was nullified by the major nutrient analysis results. Despite having different nutrient mining effects, a non-significant difference among tested plant spacings could be due to nutrient leaching.

\section{Gross income}

During summer 1998, the market price of Green Stone and Green Coronet was the same. But there was always higher market price for Green Coronet by Rs $1.0 \mathrm{~kg}^{-1}$ than that of Green Stone during harvesting period of 1999. In Sept, the market price was Rs6.0 kg-1 and at the end of Oct, the price had dropped down to Rs $4.50 \mathrm{~kg}^{-1}$. The reason behind the higher market price was due to longer life of Green Coronet during transportation than that of Green Stone. As a result, ha ${ }^{-1}$ gross income was found roughly Rs50,000.00 higher in Green Coronet than that of Green Stone while using the close spacing (Table $5)$.

Table 5. Gross return from cabbage cultivation using different varieties and plant spacing using the market price of summer 1999

\begin{tabular}{lcccc}
\hline Plant spacing, $\mathrm{cm}$ & \multicolumn{2}{c}{ Green Stone } & \multicolumn{2}{c}{ Green Coronet } \\
\cline { 2 - 5 } & Yield, tha $^{-1}$ & Gross return, Rs'000† & Yield, tha $^{-1}$ & Gross return, Rs'000 $\dagger$ \\
\hline $45 \times 20$ & 39.07 & 214.88 & 40.74 & 264.81 \\
$45 \times 30$ & 34.33 & 188.81 & 37.45 & 243.42 \\
$45 \times 40$ & 26.7 & 146.85 & 35.58 & 231.27 \\
$45 \times 50$ & 26.31 & 144.70 & 31.98 & 175.89 \\
$45 \times 60$ & 22.40 & 123.2 & 24.15 & 159.97 \\
\hline
\end{tabular}

$\dagger$ Price @ Rs5.5 kg ${ }^{-1}$ of Green Stone and Rs6.5 kg-1 of Green Coronet.

The results have clearly shown that the appropriate spacing was found $45-\times 30-\mathrm{cm}$ for rainy season cabbage for the tested hybrid varieties. Though this study failed to establish nutrient mining due to increasing plant population, it needed further investigation. Besides, spacing trial needs to be conducted for open pollinated varieties in normal season for appropriate spacing recommendation.

\section{Acknowledgements}

The author is grateful to Hill Agriculture Research Project (HARP) for funding this project. He also expresses his sincere gratitude to Dr DN Sah, Messrs MP Thapa, RC Munakarmy, DB Subba, DP Dhakal and YP Sah for their professional supports. Many thanks go to $\mathrm{Mr} \mathrm{AJ}$ Ghimire and Ms S Piya for their help to look after the experiment during his absence. He heartly appreciates the help provided by Messrs KP Gupta, JB Basnet, BP Chaudhary, JL Mandal and Mrs S Bohora for trial execution, data recording and data compilation. Last but not least, Mr PG Rood deserves special thank for his suggestions to improve the manuscript.

\section{References}

APROSC and JMA. 1995. Nepal Agriculture Perspective Plan. Agriculture Project Services Centre (APROSC), Kathmandu and John Mellor Associates Inc. (JMA), Washington DC. Prepared for the National Planning Commission, HMG/N, Asian Development Bank TA No 1854-NEP.

Berard, LS. 1990. Effect of nitrogen fertilisation on stored cabbage. I. Development of physiological disorders on tolerant and susceptible cultivars. $J$. Hort. Sci. 65(3):289-296. 
Gurung, PS. 1985. Progress report of Lumle Agriculture Centre for 1984-85 and programme for 1985-86. Pp.94-107. In: Proceedings on Fourth Workshop Seminar on Vegetables and Vegetable Seed Production (Kathmandu 25-27 Feb 1985). HMG-FAO Vegetable Seed Production Project and Vegetable Development Division, Khumaltar.

Khatiwada, PP. 1998. Effect of plant spacing on the productivity of rainy season cabbage in the high hills. PAC Working Paper No. 238. Pakhribas Agriculture Centre, Dhankuta.

Khatiwada, PP and KP Gupta. 1997. A brief visit report to high altitude sub-station, Sindhuwa. Pakhribas Agriculture Centre, Dhankuta.

Lal, G. 1996. Effect of nitrogen and spacings on yield and quality of cabbage (Brassica olerecea var capitata). Annals of Biology, Ludhiana. 12(2):242-244.

Mallik, SC and B Bhattacharya. 1996. Effect of different levels of nitrogen and different spacings on growth yield of cabbage. Environment and Ecology. 14(2):304-306.

PAC. 1990. Madhya Pahadi Chhetrama Barshaibhari Banda Kopi Utpadan. PAC Technical Bulletin. Pakhribas Agriculture Centre, Dhankuta (in Nepali).

Rai, MK and D Gaochan. 1987. Cabbage variety trial. Pp.91-92. In: Technical Report on Variety
Evaluation Trials, Seed Production and Agronomic Studies Conducted During the Year 1985-86. HMG-FAO Vegetable Seed Production Project and Vegetable Development Division, Khumaltar.

Shrestha, TN and NP Ghimire. 1996. Fresh vegetable production in Nepal. Pp.1-16. In: Proceedings on the National Seminar on Vegetable Development 11-12 June 1996. Vegetable Development Division and FAO Fresh vegetable and Vegetable Seed Production Project, Kathmandu, Nepal.

Subba, JR. 1991. Sikkim ka sag sabji. Government of Sikkim, Department of Agriculture, Gangtok (in Nepali).

Thapa, MP, PP Khatiwada, SR Gautam, G Neupane and BH Baral. 1997. Provisional recommendation for horticultural crop production in the eastern hills of Nepal: Based on research at Pakhribas Agriculture Centre (1988-1996). PAC Working Paper No. 216. Pakhribas Agriculture Centre, Dhankuta.

Tiwari, TP, MP Thapa, AJ Ghimire, SR Basnet, VR Duwadi, DK Rijal, RB Katuwal and ML Bhattarai. 1996. Visit report to Sidhuwa. Pakhribas Agricultural Centre, Dhankuta.

VDD. 1987. Nepal ma tarkari kheti. Vegetable Development Division (VDD), Khumaltar (in Nepali). 